\section{Calcium and Nitrogen Fertilization of Alstroemeria for Cut Flower Production}

\author{
Mark A. Smith, George C. Elliott' ${ }^{\mathbf{1}}$, and Mark P. Bridgen \\ Department of Plant Science, U-67, University of Connecticut, Storrs, CT 06269
}

Additional index words. inca lily, peruvian lily, foliar analysis, mineral nutrition, flower grade, stem length

\begin{abstract}
The effects of $\mathrm{Ca}$ and $\mathrm{N}$ on cut flower production of Alstroemeria were determined in separate greenhouse experiments. Calcium was supplied as $\mathrm{Ca}\left(\mathrm{NO}_{3}\right)_{2}$ and $\mathrm{CaCl}_{2}$ at 0,1 , $2,4,8$, and $12 \mathrm{mmol} \cdot \mathrm{L}^{-1}$ added to tap water containing $\mathrm{Ca}$ at $\approx 0.2 \mathrm{mmol} \cdot \mathrm{L}^{-1}$. Nitrogen was supplied as $\mathrm{KNO}_{3}$ and $\mathrm{Ca}\left(\mathrm{NO}_{3}\right)_{2}$ providing total $\mathrm{N}$ at $0,3.5,7,14,28.5$, and $57 \mathrm{mmol} \cdot \mathrm{L}^{-1}$ in tap water containing $N<0.2 \mathrm{mmol} \cdot \mathrm{L}^{-1}$. Nutrient solutions were applied at 7 - or 10 -day intervals to plants growing in a soilless medium in 2.6- or 5.5-L containers. Flowering stems were harvested when the primary florets opened. Total $\mathbf{N}$ concentration was measured in leaf tissue from the upper portion of flowering stems. Flower production was not affected by Ca supply, but increased with $\mathrm{N}$ supply to a maximum of about four stems per plant on a weekly basis at $28.5 \mathrm{mmol} \cdot \mathrm{L}^{-1}$, then decreased to less than three stems per plant at 57 mmol $\mathrm{L}^{-1}$. Nitrogen concentration in leaf tissue on a dry mass basis was maintained at 45 $\pm 3 \mathrm{~g} \cdot \mathrm{kg}^{-1}$ in plants supplied with $\mathrm{N}$ at $28.5 \mathrm{mmol} \cdot \mathrm{L}^{-1}, 52 \pm 5 \mathrm{~g} \cdot \mathrm{kg}^{-1}$ at $57 \mathrm{mmol} \cdot \mathrm{L}^{-1}$, but $<40$ $\mathrm{g} \cdot \mathrm{kg}^{-1}$ with $\mathrm{N}$ supply of $14 \mathrm{mmol} \cdot \mathrm{L}^{-1}$ or lower. Nitrogen fertilization of Alstroemeria should be managed to maintain leaf tissue $N$ close to $45 \mathrm{~g}^{\mathrm{kg}}$.
\end{abstract}

The genus Alstroemeria contains several species of herbaceous perennial monocots, and complex interspecific hybrids have been developed. Alstroemeria hybrids are grown as greenhouse cut flowers, garden flowers, or potted plants (Bridgen, 1997). The plant spreads by underground rhizomes, and has fleshy storage roots. Flowers arise in a terminal bracted umbel of cymes. Breeding programs have developed a number of cultivars offering a variety of bright colors. Cut stems have a relatively long postharvest life. Cut flower production is the major economic use of Alstroemeria, although efforts are being made to develop more cultivars with shorter stems suitable for potted plant production.

The effects of environmental factors such as temperature and light on Alstroemeria flowering have been extensively examined(Bridgen and Bartok, 1990; Healy and Wilkins, 1982, 1986a, 1986b; Keil, 1986; Lin, 1985; Lin and Molnar, 1983). Cultural practices to improve flowering, such as watering, shoot thinning, and fertilization have also been studied, but on

Received for publication 27 Jan. 1997. Accepted for publication 11 July 1997. Scientific contribution No. 1401 of the Storrs Agricultural Experiment Station, Univ. of Connecticut. This work was supported, in part, with grants from the American Floral Endowment and USDA Regional Project NE-168. We thank the UConn Soil Testing Lab for skilled technical assistance. Mention of trademark or proprietary product names or vendors is intended only for exact description, and should not be taken to imply endorsement of products or vendors named, or exclusion of other products that may be suitable. The cost of publishing this paper was defrayed in part by the payment of page charges. Under postal regulations, this paper therefore must be hereby marked advertisement solely to indicate this fact. ${ }^{1}$ To whom correspondence should be addressed. a more limited basis (Bik et al., 1980; Bik and Van den Berg, 1981; Bridgen et al., 1987; Healy and Lang, 1984; Whealy and Bridgen, 1988; Wilkins and Heins, 1976). Recommendations for $\mathrm{N}$ fertilization are inconsistent. Bik and van der Berg (1981) obtained maximum flower production with Alstroemeria 'Orchid' and 'Carmen' with $\mathrm{N}$ applied weekly at 220 mg per $12.5-\mathrm{L}$ pot. They reported that this level was considerably higher than that used by Blomme and Dambre (1979), which was not specified. Wilkins and Heins (1976) suggested application of $\mathrm{N}$ on a biweekly basis at $600 \mathrm{mg} \cdot \mathrm{L}^{-1}$ for Alstroemeria in general. Healy and Wilkins (1991) report applying $\mathrm{KNO}_{3}$ up to twice weekly with $\mathrm{N}$ at $600 \mathrm{mg} \cdot \mathrm{L}^{-1}$. Neither of these references specify the container volume or volume of fertilizer applied, so quantitative comparison is not possible. The $\mathrm{NH}_{4}^{+}: \mathrm{NO}_{3}^{-}$ ratio of $\mathrm{N}$ fertilizer does not affect flower production in Alstroemeria (Bridgen et al., $0.32 ; \mathrm{Na}_{2} \mathrm{MoO}_{4}, 0.09$.
1987), although Healy and Wilkins (1991) caution against use of ammoniacal fertilizers at low soil temperatures.

Calcium is an essential macronutrient and is frequently supplied as a cation accompanying $\mathrm{NO}_{3}^{-}$in liquid fertilizers. We are not aware of any published information regarding $\mathrm{Ca}$ nutrition of Alstroemeria, or of any specific factors (e.g., $\mathrm{pH}$ sensitivity) that might be relevant to its Ca requirements. The following studies were undertaken to determine how $\mathrm{Ca}$ and $\mathrm{N}$ fertilization affect growth and flowering of Alstroemeria.

\section{Materials and Methods}

Experiment 1. Calcium fertilization. Divisions comprising storage roots and rhizomes of Alstroemeria 'Parigo Pink' were potted on 21 Mar. 1989 in 2.6-L black plastic pots containing Fafard No. 2 growing mix (Conrad Fafard, Agawam, Mass.) with no additional amendments. Exact composition of the medium is proprietary information, but product labeling indicates that it is composed of sphagnum peat, vermiculite, and perlite and is amended with limestone and a soluble nutrient charge (Table 1). The pots were arranged in a randomized complete-block design with four pots of each treatment in a glass-covered greenhouse under natural daylength, heating setpoint temperature $10{ }^{\circ} \mathrm{C}$ night $/ 15.5{ }^{\circ} \mathrm{C}$ day, and cooling setpoint $21^{\circ} \mathrm{C}$.

Fertilizer treatments were initiated on 9 Apr. 1989, when shoots from the plants were between 5 and $10 \mathrm{~cm}$ tall. Fertilizer solutions were based on that of Hoagland's \#2 solution (Hoagland and Arnon, 1950), with six concentrations of $\mathrm{Ca}$ (Table 2), made up in tap water containing Ca at 0.20 to $0.22 \mathrm{mmol} \cdot \mathrm{L}^{-1}$. Fertilizer was applied twice at 10-d intervals, and then weekly until the termination of the experiment. For the first $48 \mathrm{~d}$ after the initial fertilization, fertilizer solution was applied at $500 \mathrm{~mL} /$ pot. Thereafter, the volume was increased to $1 \mathrm{~L} /$ pot. Leaching was not measured, but little leachate was observed. Plants were watered as needed (based on visual observations of the medium) with tap water between fertilizer applications (zero to two times, depending on weather and plant size). Flower

Table 1. Initial electrical conductivity (EC) and $\mathrm{pH}$ in aqueous slurries (1:2 by volume), and nutrient concentrations in Spurway extracts of potting media prior to planting.

\begin{tabular}{lcccccccc}
\hline & $\mathrm{EC}$ & & \multicolumn{6}{c}{ Concn $\left(\mathrm{mg} \cdot \mathrm{L}^{-1}\right)$} \\
\cline { 5 - 9 } Medium & $\left(\mathrm{dS} \cdot \mathrm{m}^{-1}\right)$ & $\mathrm{pH}$ & $\mathrm{Ca}$ & $\mathrm{Mg}$ & $\mathrm{K}$ & $\mathrm{P}$ & $\mathrm{NO}_{3}^{-}-\mathrm{N}$ & $\mathrm{NH}_{4}^{+}-\mathrm{N}$ \\
\hline Fafard \#2 & 0.6 & 5.9 & 68 & 25 & 8 & 3 & 20 & 2 \\
Fafard \#2S & 0.5 & 5.9 & 56 & 23 & 5 & 3 & 25 & 4 \\
\hline
\end{tabular}

Table 2. Nutrient solutions used to provide different concentrations of Ca. All solutions contained micronutrients as follows, in $\mu \mathrm{mol} \cdot \mathrm{L}^{-1}$ : NaFeEDTA, $90 ; \mathrm{H}_{3} \mathrm{BO}_{3}, 46.3, \mathrm{MnCl}_{2}, 9.2 ; \mathrm{ZnSO}_{4}, 0.77 ; \mathrm{CuSO}_{4}$,

\begin{tabular}{|c|c|c|c|c|c|c|c|c|}
\hline \multirow{2}{*}{$\begin{array}{l}\text { Ca concn } \\
\left(\mathrm{mmol} \cdot \mathrm{L}^{-1}\right)\end{array}$} & \multicolumn{8}{|c|}{ Salt $\left(\mathrm{mmol} \cdot \mathrm{L}^{-1}\right)$} \\
\hline & $\mathrm{NH}_{4} \mathrm{H}_{2} \mathrm{PO}_{4}$ & $\mathrm{KNO}_{3}$ & $\mathrm{Ca}\left(\mathrm{NO}_{3}\right)_{2}$ & $\mathrm{Mg}\left(\mathrm{NO}_{3}\right)_{2}$ & $\mathrm{NH}_{4} \mathrm{NO}_{3}$ & $\mathrm{NaNO}_{3}$ & $\mathrm{MgSO}_{4}$ & $\mathrm{CaCl}_{2}$ \\
\hline$\overline{0}$ & 1 & 6 & --- & 1 & 1 & 4 & 1 & $-\cdots$ \\
\hline 1 & 1 & 6 & --. & 1 & 1 & 4 & 1 & 1 \\
\hline 2 & 1 & 6 & -- & 1 & 1 & 4 & 1 & 2 \\
\hline 4 & 1 & 6 & 4 & --- & -- & --- & 2 & --- \\
\hline 8 & 1 & 6 & 4 & --- & -- & --- & 2 & 4 \\
\hline 12 & 1 & 6 & 4 & -- & --- & --- & 2 & 8 \\
\hline
\end{tabular}


harvesting commenced on 17 May 1989. Stems were harvested when the primary floral buds opened. The date of harvest, the number of florets and buds, and the length of the stem from the level of the medium to the base of the flower cymes were recorded. Flowering stems were weighed after drying for at least $4 \mathrm{~d}$ at 60 to $70^{\circ} \mathrm{C}$.

Flower production ceased 8 Aug. 1989. At that time, the number of vegetative stems per pot was recorded. Stems were removed at the surface of the growing medium, dried and weighed. Electrical conductivity (EC) was measured in aqueous extracts ( $1: 2$ by volume) of media shaken loose from the roots from each pot after stems were harvested.

Data were analyzed for statistical significance using the GLM procedures in the SAS statistical software package (SAS Institute, 1988).

Experiment 2. Nitrogen fertilization. Divisions of Alstroemeria 'Parigo Pink' were potted on 28 Oct. 1989, in 5.5-L black plastic pots containing Fafard No. 2-S (Conrad Fafard) growing medium, which is composed of sphagnum moss peat, polystyrene beads, and vermiculite, amended with lime and a soluble nutrient charge (Table 1). The pots were arranged in a randomized complete block design with four pots of each treatment in the same greenhouse with temperature setpoints as previously described. Metal halide high intensity discharge lamps (General Electric, \#E-040M) were used to provide supplemental illumination for a 16-h photoperiod (intensity not measured) until 15 Jan. 1990, at which time the photoperiod was increased to $24 \mathrm{~h}$. Lighting was discontinued on 2 Mar. 1990.

Fertilizer treatments were initiated on 26 Dec. 1989. Nitrogen was added at concentrations of $0,3.5,7,14,28.5$, and $57 \mathrm{mmol} \cdot \mathrm{L}^{-1}$ (Table 3), in tap water containing $\mathrm{N}$ at $<0.2$ $\mathrm{mmol} \cdot \mathrm{L}^{-1}$. Fertilizer solutions were applied initially every $10 \mathrm{~d}$ at $500 \mathrm{~mL} /$ pot. The volume was increased to $1 \mathrm{~L} /$ pot on $26 \mathrm{Mar}$. 1990, and the frequency was increased to once a week on 12 Apr. 1990. Leaching was not measured, but little leachate was observed. Plants were watered as needed (based on visual observations of the medium) with tap water between fertilizer applications (zero to two times, depending on weather and plant size).

Approximately one-third of the vegetative stems were removed from each plant on 20 Mar., 20 Apr., 22 May, and 23 June 1990, in order to stimulate flower production (Healy and Wilkins, 1991). Flower harvesting commenced on 29 Mar. 1990. Stems were harvested when the primary floral buds opened. The date of harvest, the number of cymes, florets and buds, and the length of the stem from the level of the medium to the base of the umbel were recorded. These data were used to grade stems using the system of Wilkins and Heins (1976), in which grade 1 stems have five or more cymes and are longer than $91 \mathrm{~cm}$, grade 2 stems have three or four cymes and are between 61 and $91 \mathrm{~cm}$ long, and grade 3 stems either have fewer than three cymes or are shorter than $61 \mathrm{~cm}$. A foliar tissue sample consisting of the eight leaves immediately

Table 3. Nutrient solutions used to provide different concentrations of $\mathrm{N}$. All solutions contained micronutrients as follows, in $\mu \mathrm{mol} \cdot \mathrm{L}^{-1}$ : NaFeEDTA, 90; $\mathrm{H}_{3} \mathrm{BO}_{3}, 46.3, \mathrm{MnCl}_{2}, 9.2 ; \mathrm{ZnSO}_{4}, 0.77 ; \mathrm{CuSO}_{4}$, $0.32 ; \mathrm{Na}_{2} \mathrm{MoO}_{4}, 0.09$.

\begin{tabular}{lcccccc}
\hline \hline $\begin{array}{l}\mathrm{N} \text { concn } \\
(\mathrm{mmol} \cdot \mathrm{L})\end{array}$ & \multicolumn{6}{c}{ Salt $\left(\mathrm{mmol} \cdot \mathrm{L}^{-1}\right)$} \\
\cline { 2 - 7 } & $\mathrm{KH}_{2} \mathrm{PO}_{4}$ & $\mathrm{MgSO}_{4}$ & $\mathrm{KNO}_{3}$ & $\mathrm{Ca}\left(\mathrm{NO}_{3}\right)_{2}$ & $\mathrm{CaCl}_{2}$ & $\mathrm{KCl}$ \\
\hline 0 & 1 & 1 & --- & -- & 2 & 5 \\
3.5 & 1 & 1 & 3.5 & -- & 2 & 1.5 \\
7 & 1 & 1 & 5 & 1 & -- & --- \\
14 & 1 & 1 & 5 & 4.5 & --- & --- \\
28.5 & 1 & 1 & 5 & 11.75 & -- & --- \\
57 & 1 & 1 & 5 & 26 & -- & --- \\
\hline
\end{tabular}

Table 4. Effect of Ca fertilization on flowering stem length and dry mass of the top growth of Alstroemeria 'Parigo Pink', and electrical conductivity (EC) in aqueous slurries ( $1: 2$ by volume) of the root medium at final harvest.

\begin{tabular}{lccc}
\hline \hline $\begin{array}{l}\text { Ca concn } \\
\left(\text { mmol } \cdot \mathrm{L}^{-1}\right)\end{array}$ & $\begin{array}{c}\text { Stem } \\
\text { length } \\
(\mathrm{cm})\end{array}$ & $\begin{array}{c}\text { Dry } \\
\text { mass } \\
(\mathrm{g} / \mathrm{plant})\end{array}$ & $\begin{array}{c}\mathrm{EC} \\
\left(\mathrm{dS} \cdot \mathrm{m}^{-1}\right)\end{array}$ \\
\hline 0 & 77.4 & 97.8 & 0.57 \\
1 & 78.8 & 91.2 & 0.54 \\
2 & 74.1 & 90.9 & 0.62 \\
4 & 75.8 & 105.0 & 0.73 \\
8 & 68.2 & 82.9 & 1.39 \\
12 & 70.7 & 60.7 & 1.84 \\
Significance & $* *$ & $* *$ & $* *$ \\
\hline
\end{tabular}

${ }^{* *}$ Significant linear effect at $P \leq 0.01$.

below the bracts at the base of the umbel was collected from each stem and dried at least $4 \mathrm{~d}$. In commercial practice, leaves are stripped from the stem prior to sale. The remainder of the flower stem was dried and weighed.

The experiment was terminated on 29 July 1990. After harvesting the flowering stems, final height of each plant was measured. The remaining stems were then separated into vegetative stems and immature floral stems, which had obvious, but unopened, floral buds. The number of vegetative stems with necrotic, limp, and brittle terminal growth was recorded. Stems in each category were counted, dried, and weighed. A sample of medium was obtained from each pot, air-dried, and extracted in $0.017 \mathrm{~mol} \cdot \mathrm{L}^{-1}$ acetic acid ( $1: 5$ by volume) for nutrient analysis (Spurway, 1943). The rhizomes and storage roots from each pot were cleaned and dried for dry mass measurement.

The flower production period was divided into nine consecutive 2-week intervals. For each interval from the second through the eighth, all the leaf samples collected from a single plant were combined. The pooled samples were ground to pass a 20 mesh screen ( $\approx 1$-mm openings) for $\mathrm{N}$ analysis using a Leco FP-428 N analyzer (Leco Corp., St. Joseph, Mich.). The first and last 2-week periods were not included because some of the treatments did not produce flower stems during these periods.

Linear regression was used to estimate the rate of flower production for each treatment during the peak production period (day 166 through day 250). Data were analyzed for statistical significance using GLM and REG procedures with the SAS statistical software package (SAS Institute, 1988).

\section{Results}

Experiment 1. Calcium fertilization. The concentration of $\mathrm{Ca}$ in the fertilizer solution had no significant effect on the number of flower stems produced per plant (16.3 to 21.5), the number of florets and flower buds on each stem (5.7 to 7.3), or the total number of stems produced (41.5 to 58.5). The average length of the floral stems and dry mass of the top growth decreased with increasing Ca concentration at 8 and $12 \mathrm{mM} \mathrm{Ca}$ with the two highest $\mathrm{Ca}$ treatments (Table 4). Electrical conductivity of the medium increased with increasing $\mathrm{Ca}$ fertilization. Conspicuous root injury was observed on plants fertilized with $\mathrm{Ca}$ at 12 $\mathrm{mmol} \cdot \mathrm{L}^{-1}$. Negative correlations were obtained between plant dry mass and EC of the medium $(r=-0.59, P=0.002)$, and between flower stem length and EC $(r=0.84, P=0.021)$.

Experiment 2. Nitrogen fertilization. The number of vegetative stems produced, the length of the flower stems, the total number of florets and flower buds produced per stem, and the total dry mass of the top growth tended to increase with $\mathrm{N}$ concentration in the fertilizer solution up to $28.5 \mathrm{mmol} \cdot \mathrm{L}^{-1}$ (Table 5). Dry mass of the rhizomes and storage roots (20.3 to $48.4 \mathrm{~g}$ ) was not affected. Cumulative flower production increased with $\mathrm{N}$ supply to 27.5 $\mathrm{mmol} \cdot \mathrm{L}^{-1}$, then decreased at $57 \mathrm{mmol} \cdot \mathrm{L}^{-1}$ (Fig. 1). Linear and quadratic effects were significant $(P \leq 0.05)$ for the effect of $\mathrm{N}$ supply on total flower production. Flower production on a weekly basis during the main period of production with $\mathrm{N}$ supplied at $28.5 \mathrm{mmol} \cdot \mathrm{L}^{-1}$ amounted about 4 flowers per plant (Table 6). Both slope and intercept coefficients differed significantly $(P \leq 0.05)$ among treatments.

Plants supplied with no $\mathrm{N}$ or $\mathrm{N}$ at 3.5 $\mathrm{mmol} \cdot \mathrm{L}^{-1}$ produced no grade $1 \mathrm{stems}$, and far fewer grade 2 stems than grade 3 stems, while plants supplied with $\mathrm{N}$ at higher concentrations produced some grade 1 stems and a higher proportion of grade 2 stems (Fig. 2). With $\mathrm{N}$ supplied at $28.5 \mathrm{mmol} \cdot \mathrm{L}^{-1}$, the sum of grade 1 and 2 stems (95) nearly equalled the number of grade 3 stems (96). The proportion 
Table 5. Effect of $\mathrm{N}$ supply on the number of vegetative stems (veg), number of florets and buds per inflorescence (florets), flower stem length, dry mass of the top growth, and plant height of Alstroemeria 'Parigo Pink'.

\begin{tabular}{lccccc}
\hline \hline $\begin{array}{l}\mathrm{N} \\
\text { concn } \\
\left(\mathrm{mmol} \cdot \mathrm{L}^{-1}\right)\end{array}$ & $\begin{array}{c}\text { No. veg. } \\
\text { stems/ } \\
\text { plant }\end{array}$ & $\begin{array}{c}\text { No. } \\
\text { florets/ } \\
\text { plant }\end{array}$ & $\begin{array}{c}\text { Flower } \\
\text { stem } \\
\text { length }(\mathrm{cm})\end{array}$ & $\begin{array}{c}\text { Plant } \\
\text { height } \\
(\mathrm{cm})\end{array}$ & $\begin{array}{c}\text { Dry } \\
\text { mass } \\
(\mathrm{g})\end{array}$ \\
\hline 0 & 14.3 & 4.5 & 48.0 & 24.0 & 12.0 \\
3.5 & 45.5 & 5.5 & 50.3 & 50.5 & 47.2 \\
7 & 37.5 & 7.0 & 61.8 & 66.3 & 89.3 \\
14 & 68.8 & 7.2 & 62.5 & 64.0 & 152.3 \\
28.5 & 75.5 & 7.7 & 64.0 & 54.0 & 185.5 \\
57 & 50.8 & 8.5 & 59.3 & 34.0 & 119.9 \\
Significance & $*$ & $* *$ & $* *$ & $* *$ & $* *$ \\
\hline$*$ *** & & & & &
\end{tabular}

*,** Significant linear effect at $P \leq 0.05$ and 0.01 , respectively.

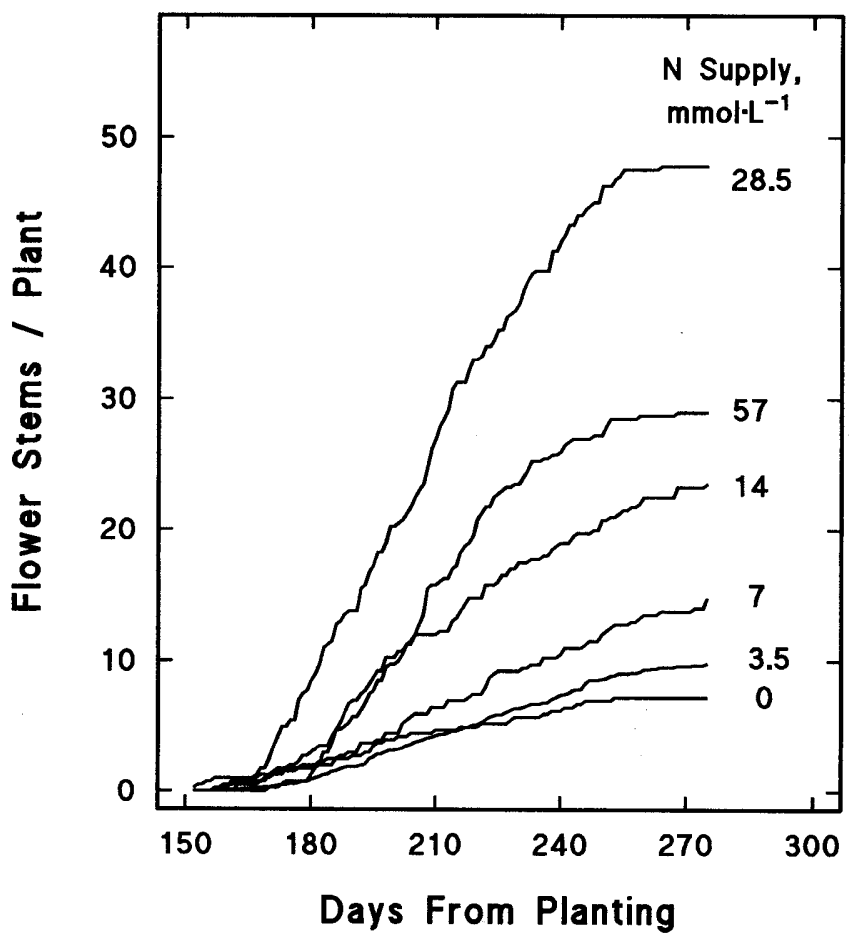

Fig. 1. Cumulative flower production by Alstroemeria fertilized with $\mathrm{N}$ at concentrations indicated. Regression coefficients for the linear phase of flower production (days 166 through 250) are given in Table 6.

Table 6. Regression equations relating the number of Alstroemeria 'Parigo Pink' flowers produced per plant per day during the period day 166 to day 250 from planting (Fig. 1) with different $\mathrm{N}$ fertilizer treatments. Regression parameter estimates are significant at least at the 0.05 level.

\begin{tabular}{llr}
\hline \hline concn $\left(\mathrm{mmol} \cdot \mathrm{L}^{-1}\right)$ & Predictive equation & $R^{2}$ \\
\hline 0 & $\mathrm{Y}=0.07$ (day)-10.9 & 0.98 \\
3.5 & $\mathrm{Y}=0.11$ (day)-17.9 & 0.99 \\
7 & $\mathrm{Y}=0.14$ (day)-23.4 & 0.99 \\
14 & $\mathrm{Y}=0.26$ (day) -42.0 & 0.98 \\
28.5 & $\mathrm{Y}=0.56$ (day)-92.1 & 0.99 \\
57 & $\mathrm{Y}=0.39$ (day)-68.1 & 0.98 \\
\hline
\end{tabular}

of grade 3 stems increased during the latter half of the production period, and they comprised the majority of stems harvested beginning with the fourth interval for the 3.5 and 7 $\mathrm{mmol} \cdot \mathrm{L}^{-1}$ treatments, and the fifth interval for the $14,28.5$, and $57 \mathrm{mmol} \cdot \mathrm{L}^{-1}$ treatments.

Nitrogen concentration of leaf tissue from flowering stems increased with $\mathrm{N}$ supply (Fig. $3 \mathrm{~A})$. Within treatments, the concentration of $\mathrm{N}$ did not change significantly $(P \leq 0.05)$ during the production period when $\mathrm{N}$ was supplied at $0,3.5,28.5$, or $57 \mathrm{mmol} \cdot \mathrm{L}^{-1}$, but tended to decrease with time at 7 or $14 \mathrm{mmol} \cdot \mathrm{L}^{-1}$ (Fig.
3B). Maximum flower production, with $\mathrm{N}$ at $28.5 \mathrm{mmol} \cdot \mathrm{L}^{-1}$, was associated with tissue $\mathrm{N}$ levels maintained close to $45 \mathrm{~g} \cdot \mathrm{kg}^{-1}$ (Fig. 4).

Nitrate-N concentrations in Spurway extracts of root media were less than $5 \mathrm{mg} \cdot \mathrm{L}^{-1}$ with $\mathrm{N}$ supply up to $14 \mathrm{mmol} \cdot \mathrm{L}^{-1}$, increasing to $48 \mathrm{mg} \cdot \mathrm{L}^{-1}$ at $28.5 \mathrm{mmol} \cdot \mathrm{L}^{-1}$ and $60 \mathrm{mg} \cdot \mathrm{L}^{-1}$ at $57 \mathrm{mmol} \cdot \mathrm{L}^{-1}$. Phosphorus and $\mathrm{K}$ concentrations were lowest in extracts of media fertilized with $\mathrm{N}$ at 14 or $28.5 \mathrm{mmol} \cdot \mathrm{L}^{-1}$. Electrical conductivity ranged from 0.62 to $0.88 \mathrm{dS} \cdot \mathrm{m}^{-1}$ in media fertilized with $\mathrm{N}$ at 0 to $14 \mathrm{mmol} \cdot \mathrm{L}^{-1}$, increasing to $1.4 \mathrm{dS} \cdot \mathrm{m}^{-1}$ at $28.5 \mathrm{mmol} \cdot \mathrm{L}^{-1}$ and to $2.7 \mathrm{dS} \cdot \mathrm{m}^{-1}$ at $57 \mathrm{mmol} \cdot \mathrm{L}^{-1}$.

\section{Discussion}

Calcium fertilization. Plants receiving fertilizer solution with no added $\mathrm{Ca}$ evidently acquired enough $\mathrm{Ca}$ from the lime incorporated in the growing medium, as well as from $\mathrm{Ca}$ in irrigation water, to sustain levels of growth and flower production similar to those in plants supplied with $\mathrm{Ca}$ up to $4 \mathrm{mmol} \cdot \mathrm{L}^{-1}$. Calcium concentration in tap water was less than $0.25 \mathrm{mmol} \cdot \mathrm{L}^{-1}$ and the initial media $\mathrm{Ca}$ concentration (Table 1) was in the low range of recommended values for floricultural crops (Koths et al., 1980). Monocotyledonous plants generally have a low Ca requirement (Marschner, 1995). Alstroemeria evidently conforms to this general tendency, since supplemental $\mathrm{Ca}$ was not required to sustain growth and flowering. Therefore, little or no Ca fertilization should be necessary for Alstroemeria production.

Fertilizer treatments supplying $\mathrm{Ca}$ at less than $12 \mathrm{mmol} \cdot \mathrm{L}^{-1}$ had no negative effects on growth. Calcium is generally regarded as nontoxic to plants (Marschner 1995). The negative effects of high $\mathrm{Ca}$ fertilizer treatments might be attributed either to the effect of fertilizer solutions on the soluble salt concentration of the growing medium or the use of $\mathrm{Cl}^{-}$ as a counterion for $\mathrm{Ca}^{2+}$ at 8 and $12 \mathrm{mmol} \cdot \mathrm{L}^{-1}$. With $\mathrm{Ca}$ at $12 \mathrm{mmol} \cdot \mathrm{L}^{-1}$, the $\mathrm{EC}$ of media extracts was in the high range for established crops (Koths et al., 1980). The negative correlations obtained between EC and shoot dry mass, and EC and flowering stem length, support the contention that EC was the most likely factor restricting growth. Fenn et al. (1987) observed growth inhibition of Phaseolus vulgaris with $\mathrm{CaSO}_{4}$ at $16 \mathrm{mmol} \cdot \mathrm{L}^{-1}$. They suggested that this was due to the increase in soluble salts at that concentration. In our experiment, $\mathrm{Cl}^{-1}$ concentration was $16 \mathrm{mmol} \cdot \mathrm{L}^{-1}$ in the $12 \mathrm{mmol} \cdot \mathrm{L}^{-1} \mathrm{Ca}$ fertilizer solution, so the possibility of $\mathrm{Cl}^{-}$toxicity cannot be ruled out. Little information is available on $\mathrm{Cl}^{-}$toxicity pertinent to this study, but $\mathrm{Cl}^{-}$levels in excess of $4 \mathrm{mmol} \cdot \mathrm{L}^{-1}$ are considered excessive for water used for irrigation of greenhouse crops (Petersen, 1996).

Nitrogen fertilization. Alstroemeria plants fertilized with $\mathrm{N}$ at $28.5 \mathrm{mmol} \cdot \mathrm{L}^{-1}$ produced more flowers of higher quality with earlier onset of flowering than did plants fertilized with lower or higher concentrations. The maximum top dry mass at final harvest in plants that were provided $\mathrm{N}$ at $28.5 \mathrm{mmol} \cdot \mathrm{L}^{-1}$ can be accounted for by the number of vegetative stems, since the average dry mass per stem was relatively constant within $\mathrm{N}$ treatments from 7 to $57 \mathrm{mmol} \cdot \mathrm{L}^{-1}$.

According to general interpretive guidelines for Spurway extraction (Koths et al., 1980), $\mathrm{NO}_{3}^{-}-\mathrm{N}$ concentrations were low in all treatments with $\mathrm{N}<28.5 \mathrm{mmol} \cdot \mathrm{L}^{-1}$, high at $28.5 \mathrm{mmol} \cdot \mathrm{L}^{-1}$, and excessive at $57 \mathrm{mmol} \cdot \mathrm{L}^{-1}$. Phosphorus and $\mathrm{K}$ were in the low range in media with $\mathrm{N}$ at 14 or $28.5 \mathrm{mmol} \cdot \mathrm{L}^{-1}$, but were in the medium range with other $\mathrm{N}$ concentrations. These observations suggest that $\mathrm{P}$ or $\mathrm{K}$ might have become limiting factors in plant nutrition with $\mathrm{N}$ at $28.5 \mathrm{mmol} \cdot \mathrm{L}^{-1}$. Further 


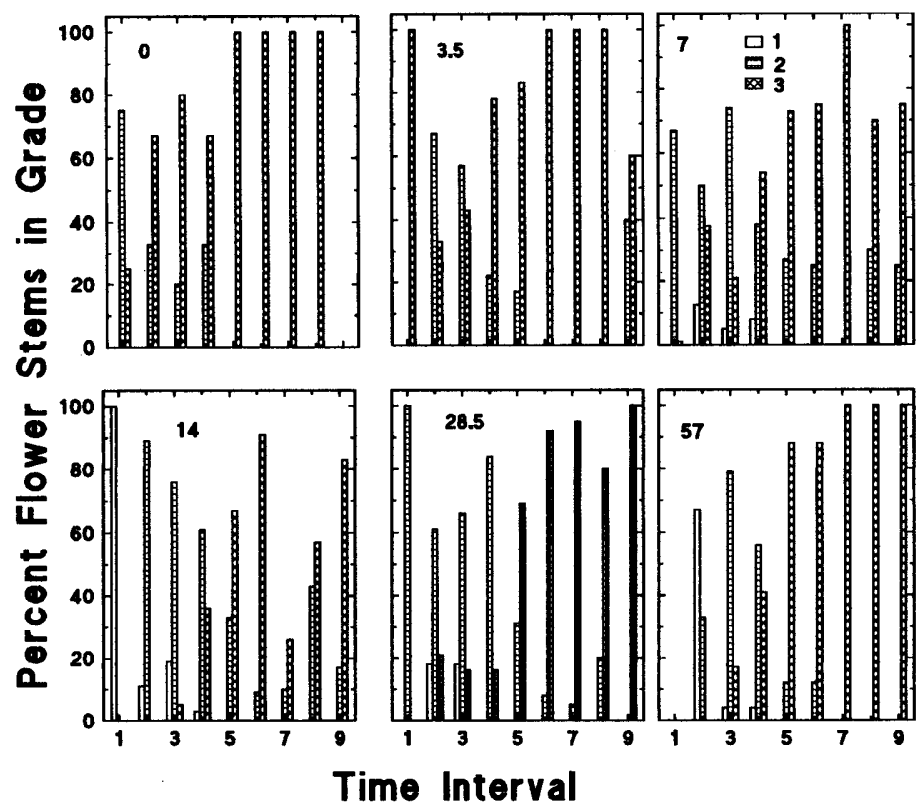

Fig. 2. Percent of Alstroemeria flower stems produced in each grade at $\mathrm{N}$ fertilizer concentrations $\left(\mathrm{mmol} \cdot \mathrm{L}^{-1}\right)$ indicated, during successive 2 -week intervals beginning with the first flower harvest.

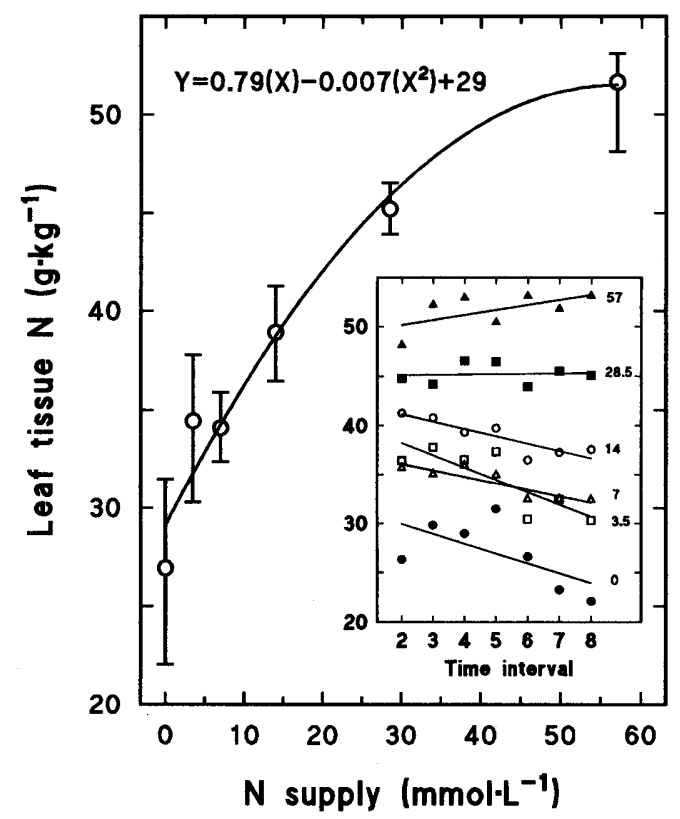

Fig. 3. Effect of $\mathrm{N}$ supply on $\mathrm{N}$ concentration (dry mass basis) of standard leaf tissue (eight leaves immediately below the bracts subtending the umbel) of Alstroemeria during the flower production period. Each point is the mean of 28 samples, each sample comprising standard leaf tissue pooled from all flowering stems harvested from an individual plant during an interval of 2 weeks. Error bars show range of observations. Inset: $\mathrm{N}$ concentration over time for varying fertilizer $\mathrm{N}$ treatments. Each point is the mean of four samples.

research will be required to determine optimal rates of $\mathrm{P}$ and $\mathrm{K}$ fertilization for Alstroemeria. When $\mathrm{N}$ was supplied at $57 \mathrm{mmol} \cdot \mathrm{L}^{-1}$, plants were evidently unable to completely utilize the $\mathrm{NO}_{3}^{-}$and other ions provided, thus increasing electrical conductivity in the medium.

Reduction in stem quality over time was not related to $\mathbf{N}$ supply, as it occurred at approximately the same time in all of the treatments, and was attributable for the most part to decreased flower stem length. Healy and Lang (1984) observed that Alstroemeria tends to produce progressively shorter shoots as stems are removed from the rhizome.

Previous reports have not provided consistent recommendations for $\mathrm{N}$ fertilization of Alstroemeria. For example, Healy and Wilkins (1991) report fertilizing twice weekly with $\mathrm{KNO}_{3}$ providing $\mathrm{N}$ at $600 \mathrm{mg} \cdot \mathrm{L}^{-1}$, without any adverse effects. Volume was not specified, so the quantity cannot be calculated. In this experiment, fertilizing once weekly with $\mathrm{N}$ at 57 $\mathrm{mmol} \cdot \mathrm{L}^{-1}\left(798 \mathrm{mg} \cdot \mathrm{L}^{-1}\right)$ inhibited flower production. On the other hand, Bik and van der
Berg (1981) obtained maximum flower production with $\mathrm{N}$ applied weekly at $220 \mathrm{mg} / 12.5$ $\mathrm{L}$ pot, which is considerably less than that applied in the $28.5 \mathrm{mmol} \cdot \mathrm{L}^{-1}$ treatment in this experiment $(400 \mathrm{mg} / 5.5 \mathrm{~L}$ pot on a weekly basis). These discrepancies are most likely due to differences in crop growth potential as the result of differences in the growing environment, or the use of different cultivars.

Low $\mathrm{Ca}$ requirement coupled with tolerance of $\mathrm{Ca}$ up to $8 \mathrm{mmol} \cdot \mathrm{L}^{-1}$ and relative indifference to $\mathrm{NH}_{4}^{+}: \mathrm{NO}_{3}^{-}$ratio makes preparation of liquid fertilizer for Alstroemeria relatively simple. The $\mathrm{N}$ requirement can be fulfilled with combinations of $\mathrm{NH}_{4}^{+}$and $\mathrm{NO}_{3}^{-}$ salts, using $\mathrm{Ca}^{2+}$ as a variable cation depending on requirements for other nutrients and for $\mathrm{NH}_{4}^{+}: \mathrm{NO}_{3}^{-}$ratio to maintain desired $\mathrm{pH}$.

Optimal fertilization of a crop must be related to growth potential. The use of tissue analysis may be the most accurate method of determining the appropriate rate of $\mathrm{N}$ fertilization for a given set of growing conditions. We found the optimum concentration of $\mathrm{N}$ in $\mathrm{Al}$ stroemeria leaf tissue to be $45 \pm 3 \mathrm{~g} \cdot \mathrm{kg}^{-1}$, in agreement with Bik et al. (1980), who reported $\mathrm{N}$ concentrations from 40 to $45 \mathrm{~g} \cdot \mathrm{kg}^{-1}$ in productive plantings of Alstroemeria. Nitrogen fertilization of Alstroemeria should be adjusted to maintain leaf tissue $\mathrm{N}$ close to 45 $\mathrm{g} \cdot \mathrm{kg}^{-1}$. Tracking tissue $\mathrm{N}$ would be fully justified in Alstroemeria as it is a relatively longterm crop that is most productive when tissue $\mathrm{N}$ is relatively constant throughout its reproductive life.

\section{Literature Cited}

Bik, A., T.H. Edens, Th. van der Krogt, J. van der Kwaak, C. Vonk Noordergraaf, W. den Boer, L. Dellaert, J.P.C. Knoppert, Jac. van Paassen, J.J. van Schie, L. Vellekoop, and B. Stein. 1980. Cultural directions for Alstroemeria, Bulletin \#20. p. 21-30. Aalsmeer, Netherlands.

Bik, A.R. and Th.J.M. van den Berg. 1981. Nitrogen and potassium fertilization of the Alstroemeria cultivars 'Orchid' and 'Carmen' grown on peat. Acta Hort. 126:287-292.

Blomme, R. and P. Dambre. 1979. De teelt en het bemestingsonderzoek bij Alstroemeria. Verbondsnieuws voor de Belgische Sierteelt 23:561565. (Cited by Bik and van den Berg, 1981.)

Bridgen, M.P. 1997.Alstroemeria. In: Ball, V.(ed.). (In Press.) Ball RedBook, 16th ed. Geo. J. Ball Publishing, West Chicago, Ill.

Bridgen, M.P. and J.W. Bartok. 1990. Evaluation of a growing medium cooling system and its effects on the flowering of Alstroemeria. HortScience 25:1592-1594.

Bridgen, M.P., B.B. Bible, and P. Winski. 1987. Response of Alstroemeria to rates and sources of nitrogen. HortScience 22:65. (Abstr.)

Fenn, L.B., R.M. Taylor, and G.L. Horst. 1987. Phaseolus vulgaris growth in an ammoniumbased nutrient solution with variable calcium. Agron. J. 79:89-91.

Healy, W.E. and D. Lang. 1984. Alstroemeria observations-1984. Colorado Greenhouse Growers Res. Bul. 414:2.

Healy, W.E. and H.F. Wilkins. 1982. Responses of Alstroemeria 'Regina' to temperature treatments prior to flower-inducing temperatures. Scientia Hort.17:383-390.

Healy, W.E. and H.F. Wilkins. 1986a. Relationship 


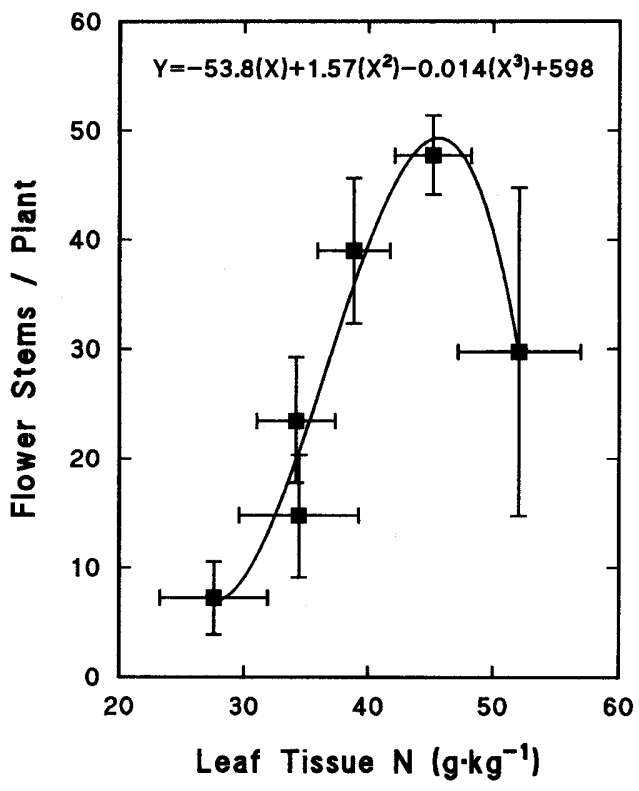

Fig. 4. Association between Alstroemeria flower production and mean $\mathrm{N}$ concentration (dry mass basis) of standard leaf tissue. Data for flower production are the cumulative means of 4 plants, while $\mathrm{N}$ concentration data represent averages for four pooled samples for each of seven sampling intervals. Error bars show standard deviations.

between rhizome temperatures and shoot temperatures for floral initiation and cut flower production of Alstroemeria 'Regina'. J. Amer. Soc. Hort. Sci. 111:94-97.

Healy, W.E. and H.F. Wilkins. 1986b. Influence of light treatments before and after induction treatment on flowering of Alstroemeria 'Regina'. HortScience 21:1390-1392.

Healy, W.E. and H.F. Wilkins. 1991. Alstroemeria: The cut flower crop, p. 311-316. In: V. Ball (ed.). Ball RedBook, 15th ed. Geo. J. Ball Publishing, West Chicago, Ill.

Hoagland, D.R. and D.I. Arnon. 1950. The waterculture method for growing plants without soil. Calif. Agr. Expt. Sta. Circ. 347.

Keil,L. 1986. Alstroemeria culture. ColoradoGreenhouse Growers Assoc. Res. Bul. 436:1-3.

Koths, J.S., R.W. Judd, Jr., J.J. Maisano, Jr., G.F. Griffin, J.W. Bartok, Jr., and R.A. Ashley. 1980. Nutrition of greenhouse crops. Northeast States Coop. Ext. Serv. Bul. NE220.

Lin, W.C. 1985. Influence of soil cooling and high intensity lighting on the growth and flowering of Alstroemeria 'Regina'. HortScience 20:380381.

Lin, W.C. and J.M. Molnar. 1983. Effect of photoperiod and high intensity supplementary lighting on flowering of Alstroemeria 'Orchid' and 'Regina'. J. Amer. Soc. Hort. Sci. 108:914-917.

Marschner, H. 1995. Mineral nutrition of higher plants. 2nd ed. Academic, Orlando, Fla.

Petersen, F.H. 1996. Water testing and interpretation. In: D.W. Reed (ed.). Water, media, and nutrition for greenhouse crops. Ball Publishing, Batavia, Ill.

SAS Institute. 1988. SAS/STAT users guide, release 6.03 ed. SAS Inst., Cary, N.C.

Spurway, C.H. 1943. Soil fertility control for greenhouses. Michigan Agr. Expt. Sta. Spec. Bul. 325.

Whealy, C.A. and M.P. Bridgen. 1988. Grower Expo recipe for potted plant success-Alstroemeria. Grower Talks. June, p. 63.

Wilkins, H.F. and R.D. Heins. 1976. Alstroemeria general culture. Florists' Rev. 159(4121):30$31 \mathrm{ff}$. 